Ann. Zootech., 1984, 33 (1), 51-58

\title{
Effects of sorbitol and added bile salts on food utilisation and morphological changes in the liver, gall-bladder and caeca of young chicks
}

\author{
R. KUSSAIBATI and B. LECLERCQ \\ I.N.R.A., Station de Recherches avicoles \\ Centre de Recherches de Tours-Nouzilly, F 37380 Monnaie
}

\begin{abstract}
Summary
Three week-old male chicks of a commercial breed were used to study the effect of sorbitol or added bile salts on the apparent metabolisable energy (AME) values and the apparent fat digestibility (AFD) coefficients of a diet rich in saturated lipids (15 p. 100 beef tallow). The experimental diet was given alone or supplemented with different levels of sorbitol $(0.5,1$ or 2 p. 100) or bile salts $(0.5 \mathrm{p}, 100)$, added at the expense of dietary glucose. Both short-term (acute) and long-term (chronic) sorbitol intake periods were compared. Food efficiency and morphological changes in liver, gall-bladder and caeca were also investigated.

The results showed that both the AME values and the AFD coefficients were significantly increased $(+4.6$ p. 100 and +16 p. 100 respectively, $P<0.01)$ when bile salts were added to the diet. However, neither acute nor chronic sorbitol intake, at any of the levels studied, seemed to affect these two criteria. Chicks fed on the bile salt supplemented diet showed two- to three fold increases in the size of the gall-bladder and its freeze-dried weight increased by more than twofold $(P<0.01)$. None of the dietary additions affected liver or caecal weights.
\end{abstract}

Key words : Bile salts, sorbitol, fat digestibility, metabolisable energy.

\section{Introduction}

Sorbitol is a naturally-occurring polyhydric alcohol which can be synthesised industrially from glucose by reduction. It is used as cholagogue, lipotropic agent and mild laxative in human medicine. The main action of sorbitol is, however, the stimulation of bile salts concentration and secretion, in man (PLESSIER, 1960; GranchARov, 1973) in the dog (Dubich \& KreKniN, 1969 ; BeCKorovainaya, 1971) and in the preruminant calf (THIVEND et al., 1983).

In chickens, work has been performed to study the effects of sorbitol on body weight gain and on the synthesis and sparing of B group vitamins. It was found that the addition of 1.6 to 3.6 p. 100 of sorbitol to a growing chick diet improved final body weight (MAZANowski \& MAZanowska, 1965). However, although increasing this 
level to 10 or 20 p. 100 depressed body weight gain and caused caecal enlargement, it was found to enhance the concentration of caecal biotin at suboptimal levels of dietary biotin (BAuer \& Griminger, 1980). On the other hand, the addition of small quantities of bile salts to the diet of young chicks improved the digestibility of dietary fat, especially that of saturated fatty acids (Gomez \& Polin, 1974, 1976; KatONGOLE \& March, 1980 ; Kussaibati, Gulllaume \& LeclercQ, $1982 \mathrm{a}, \mathrm{b}$; Polin \& Hussein, 1982) and as a result the metabolisable energy value of the diet was also increased (Kussaibati, Guillaume \& LeclercQ, $1982 \mathrm{a}$, b).

The work reported here was undertaken in order to study the effects of various levels of sorbitol compared to those of added bile salts on food utilisation in young growing chicks, with special reference to dietary saturated fat. Furthermore the effects of these dietary additions on the morphology of the liver, gall-bladder and caeca were examined.

\section{Material and methods}

Thirty-six 1-day old male chicks of a broiler commercial breed (Hubbard) homogeneous with respect to body weight, were selected from a flock of 75 birds. Six groups (A, B, C, D, E and F) of 6 birds each were formed, the experiment unit being a single bind. The birds were raised and fed in individual cages provided with feeders and drinking founts and placed in a temperature and light controlled room. The temperature was reduced from hatch at a rate of $2{ }^{\circ} \mathrm{C} /$ week from 28 to $20^{\circ} \mathrm{C}$. Lighting was provided for $22 \mathrm{hr} / \mathrm{d}$ during the whole experiment.

\section{TABLE 1}

Composition of the diet.

Composition du régime alimentaire.

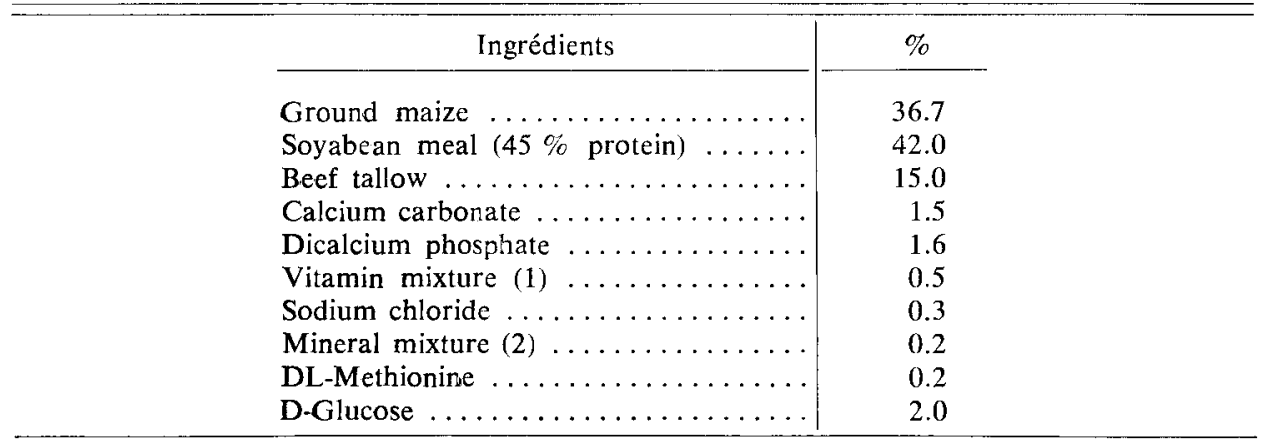

(1), (2) : See Kussaibati et al., 1982 b.

The chicks were fed on a proprietary commercial diet ad libitum for the first $8 \mathrm{~d}$ following hatch and the experimental diet (table 1) based on ground maize and soya- 
bean meal but containing 15 p. 100 beef tallow was introduced at $9 \mathrm{~d}$ of age. This diet was given ad libitum to 5 groups : without supplementation (group A), or supplemented with either 0.5 p. 100 bile salts (B) (a mixture of sodium cholate and sodium deoxycholate Sigma) or 0.5 p. 100 (C), 1 p. 100 (D) or 2 p. 100 (E) sorbitol (Merck) at the expense of dietary glucose. Food intake and live body weight gain of all the birds of these 5 groups were measured for 11 days in order to estimate food efficiency during this period. In addition the effects of chronic sorbitol or bile salts on food utilisation and the morphology of the liver, gall-bladder and caeca were also studied. Birds of the 6 th group $(F)$ were maintained on the commercial diet from hatch up to $19 \mathrm{~d}$ of age and the experimental diet supplemented with 1 p. 100 sorbitol was introduced on the $21 \mathrm{nd}$ day in order to study the effects of acute sorbitol intake on food utilisation.

Apparent metabolisable energy (AME) values and apparent fat digestibility (AFD) coefficients were determined using the total collection method. The $5 \mathrm{~d}$ balance period was divided into fasting, feeding and refasting periods. At $20 \mathrm{~d}$ of age birds of all groups were fasted for $1 \mathrm{~d}$, then the appropriate experimental diet in mash form was distributed ad libitum for $3 \mathrm{~d}$. This was followed by a $1 \mathrm{~d}$ refasting period necessary to ensure complete clearance of the digestive tract of residues of food origin. Excreta were totally collected during the $3 \mathrm{~d}$ feeding plus the $1 \mathrm{~d}$ refasting periods :

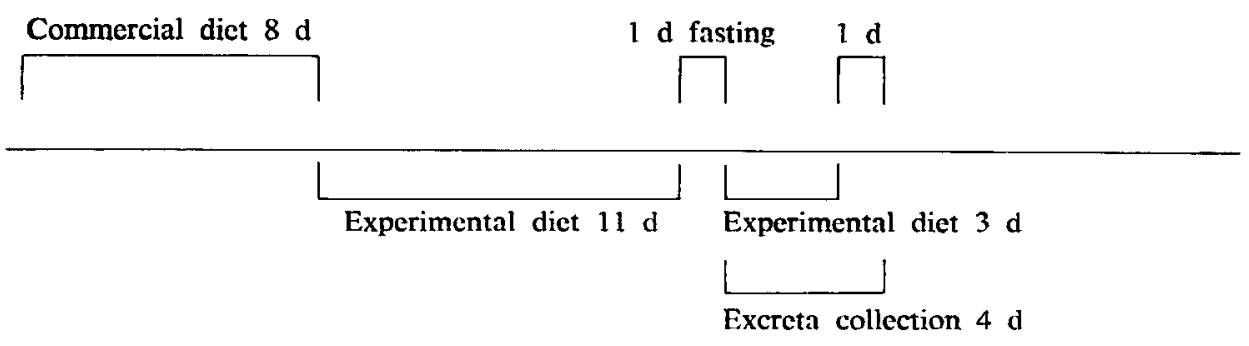

At $25 \mathrm{~d}$ of age and after excreta collection, all the birds, except those of group (F), were killed by intracardiac injection of $0.5 \mathrm{ml}$ nembutal (Abbot). The liver, the intact gall-bladder and both caeca with their contents were removed, frozen, freeze dried and weighed. Caecal lengths were measured before freezing.

The collected excreta were frozen, freeze-dried, weighed and a homogeneous sample was ground finely in a small grinder. Before weighing, excreta were allowed to stand for $24 \mathrm{~h}$ to reach equilibrium with atmospheric moisture. Gross energy of feed and excreta were measured by an adiabatic bomb calorimeter. Crude fat was extracted using chloroform : methanol $(2: 2, \mathrm{v} / \mathrm{v})$ according to the method of FolcH, Lees \& Sloane-STANley (1957), with certain modifications for extracting faecal lipids (HAKANSSON, 1974). Extracted lipids were purified using pure benzene according to the method described by Delpech, Guezel. \& Leclerce (1966), and quantitative determination of fatty acids was described elsewhere (Kussaibati, Guillaume \& LECLERCQ, 1982 b).

An analysis of variance (SNEDECOR, 1956) was used to test the significance of treatment factors. 


\section{Results and discussion}

After feeding the chicks on the experimental diets for $11 \mathrm{~d}$, it was found that neither food intake nor live body weight gain were significantly affected by the addition of 0.5 p. 100 bile salts or different levels of sorbitol $(0.5$ p. 100,1 p. 100 and 2 p. 100) to the diet (table 2). However, MazAnOwSKI \& Mazanowska (1965) demonstrated that the final live body weights of growing chicks were improved as a result of adding sorbitol to their diet, but no explanation of this phenomenon was given by the authors.

\section{TABLE 2}

Effect of sorbitol and bile salts on feed efficiency.

Effet du sorbitol et des sels biliaires sur l'efficacité alimentaire.

\begin{tabular}{c|c|c|c|c}
\hline Group & $\begin{array}{c}\text { Sorbitol (S) or } \\
\text { bile salts (BS) } \\
\text { level in diet (\%) }\end{array}$ & $\begin{array}{c}\text { Feed intake } \\
\text { g/11 d }\end{array}$ & $\begin{array}{c}\text { B.W. gain } \\
\text { g/11 d }\end{array}$ & $\frac{\text { B.W. gain }}{\text { Feed intake }} \times 100$ \\
\hline A & - & $410 \pm 17$ & $274 \pm 11$ & $66.8 \pm 1.0$ \\
B & BS 0.5 & $436 \pm 21$ & $292 \pm 17$ & $66.7 \pm 1.0$ \\
C & S 0.5 & $420 \pm 22$ & $270 \pm 18$ & $66.2 \pm 1.5$ \\
D & S 1.0 & $407 \pm 12$ & $268 \pm 12$ & $65.7 \pm 1.1$ \\
E & S 2.0 & $440 \pm 14$ & $292 \pm 10$ & $66.3 \pm 1.7$ \\
\hline
\end{tabular}

Values are means of 6 replicates \pm S.E.

Table 3

Effect of sorbitol $(S)$ and bile salts (BS)

on the apparent metabolisable energy (AME) values and apparent fat digestibility (AFD) coefficients.

Effet du sorbitol et des sels biliaires

sur les valeurs d'énergie métabolisable apparente (AME)

et les coefficients d'utilisation digestive apparente des lipides (AFD).

\begin{tabular}{|c|c|c|c|c|}
\hline Group & $\begin{array}{r}\text { Sorbito } \\
\text { bile salts }\end{array}$ & $\begin{array}{l}1 \text { (S) or } \\
\text { (BS) }(\%)\end{array}$ & $\begin{array}{l}\text { AME values } \\
(\text { Kcal } / \mathrm{kg})\end{array}$ & $\begin{array}{l}\text { AFD coefficients } \\
(\%)\end{array}$ \\
\hline A & & 0 & $3451 \pm 35$ & $75.8 \pm 1.9$ \\
\hline \multirow[t]{2}{*}{ B } & BS & 0.5 & $3611 \pm 20^{*}$ & $87.9 \pm 1.1^{*}$ \\
\hline & & & \multicolumn{2}{|c|}{ Chronic intake of sorbitol $(11+3 \mathrm{~d})$} \\
\hline $\mathrm{C}$ & & 0.5 & $3428 \pm 14$ & $74.2 \pm 1.6$ \\
\hline $\mathrm{D}$ & & 1.0 & $3433 \pm 31$ & $77.1 \pm 1.6$ \\
\hline \multirow[t]{2}{*}{$\mathbf{E}$} & & 2.0 & $3424 \pm 19$ & $75.2 \pm 0.6$ \\
\hline & & & \multicolumn{2}{|c|}{ Acute intake of sorbitol (3 d) } \\
\hline $\mathbf{F}$ & $\mathbf{S}$ & 1.0 & $3461 \pm 39$ & $76.0 \pm 1.7$ \\
\hline
\end{tabular}

Values are means of 6 replicates \pm S.E.

* $\mathbf{P}<0.01$. 
Results concerning AME values and AFD coefficients are shown in table 3. Both the AME value and the AFD coefficient were significantly $(P<0.01)$ increased by 4.6 p. 100 and 16 p. 100 respectively, when 0.5 p. 100 bile salts were added to the diet. It is clear that the increase in AME values could be explained by the improvement of AFD. Indeed the AFD coefficient increased from 75.8 to 87.9 p. 100 as a result of bile salt addition. If it is assumed that the beef tallow has a gross energy value of $9000 \mathrm{Kcal} / \mathrm{kg}$, then it might be expected that its AME value would increased from 1023 to $1186 \mathrm{Kcal}$ at 15 p. 100 inclusion; the difference between these values, $163 \mathrm{Kcal}$, is very close to the difference between the AME values of diets A and B (160 Kcal).

The apparent digestibility of total fatty acids (table 4) was significantly $(P<0.01)$ increased by more than 14 p. 100 , when 0.5 p. 100 bile salts were added to the diet. This improvement was noted for all fatty acids but especially saturated ones : palmitic $(+25.7$ p. 100) and stearic $(+42.4$ p. 100). The advantages of adding bile acids or salts with respect to fat digestibility in young chicks has already been demonstrated by many authors (Gomez \& Polin, 1974, 1976; Katongole \& March, 1980 ; KusSaibati, Gulllaume \& LeclercQ, $1982 \mathrm{a}, \mathrm{b}$ ). The effect of bile salts in this trial was highly pronounced and this could be attributed to the use of pure beef tallow rich in long chain saturated fatty acids. On the contrary, sorbitol had no effect on these parameters (AME and AFD), irrespective of the level of incorporation or the duration of feeding it. However, a slight but non-significant improvement in total fatty acid digestibility was observed when acute administration of sorbitol was used. The same tendency was observed for all fatty acids. Nevertheless, such a faint improvement is negligible from practical point of view.

It has been found that sorbitol administration can increase bile secretion in man and some domestic animals. In man, ingested sorbitol liberates an endogenous cholecystokinin, an intestinal hormone responsible for bile secretion and evacuation from the gall-bladder (PLESsIER, 1960). In addition, sorbitol has been found to shorten dietary transit time by 38 p. 100 and to increase the hourly bile acid excretion rate by 31 p. 100 (HARDISON, TomaszewsKi \& Grundy, 1979). As intestinal cells producing cholecystokinin have recently been demonstrated in the upper and lower ileum of chicken (RAWDON \& ANDREW, 1981), sorbitol could increase bile secretion via its cholecystokenitic action. However, any action leading to a shortening in the transit time of the ingesta must be negligible, because intestinal transit is very rapid in chickens. No signs of diarrhoea, due to the sorbitol administration were detected during the present experiment and it may be that bile secretion was increased in these chicks but not sufficiently to produce a detectable improvement on fat digestibility.

Caecal enlargement, reported by Morgan \& YUdKIN (1962) and BAUER \& GRIMINGER (1980) when high quantities of sorbitol (10-20 p. 100) were added to the diet was not observed in the present investigation (table 5). This may be due to the lower levels of sorbitol ( 2 p. 100 maximum) used here.

The gall-bladder enlargement (two - to threefold increases in the size and freezedried weight; table 5) which was observed when 0.5 p. 100 bile salts were added to the diet could be explained by the daily continuous accumulation of these salts (after being metabolized) in the gall-bladder. It is well established, however, that bile secretion and absorption are continuous processes (SMall, Dowling \& Redinger, 1972) and only a very small quantity of the bile acids fails to be absorbed (EASTwOoD, 1973). Finally, none of the dietary additions affected liver weight. 
TABLE 4

Apparent digestibility of fatty acids (\%).

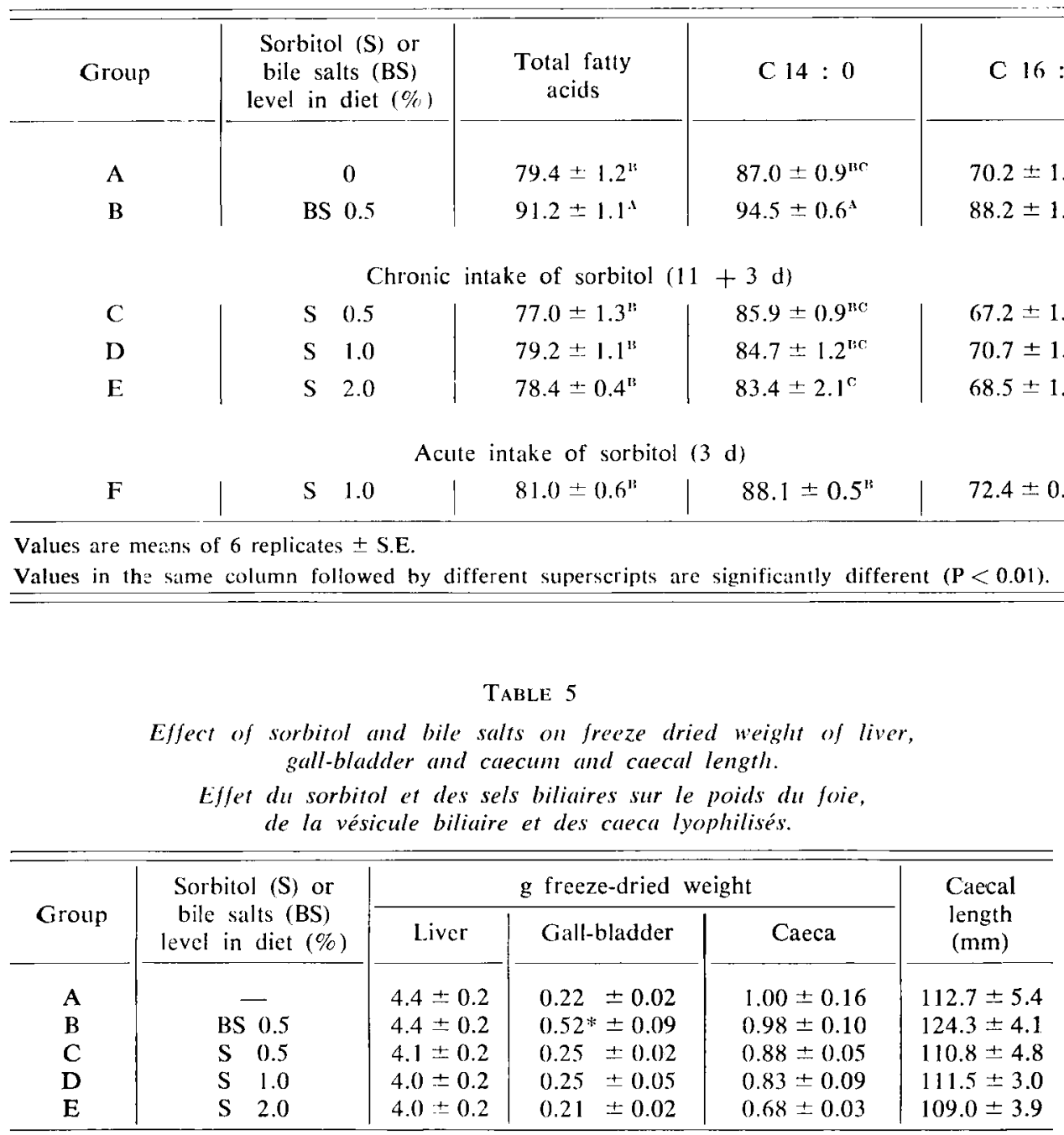

Values are means of 6 replicates \pm S.E.

* $\mathbf{P}<0.01$.

It was concluded that sorbitol, in contrast to bile salts, had no effect on food utilisation expressed as AME value or AFD coefficient terms when added in small quantities to a young chicks' diet.

\section{Acknowledgments}

The authors wish to thank Mrs. L. Derouet and Mr. J.M. Hallouis for their skilful technical assistance, and Dr. J. Williams for his supervision of the English manuscript. 
Digestibilité apparente des acides gras.

\begin{tabular}{c|c|c|c|c}
\hline $\mathrm{C} 16: 1$ & $\mathrm{C} 18: 0$ & $\mathrm{C} 18: 1$ & $\mathrm{C} 18: 2$ & $\mathrm{C} 18: 3$ \\
\hline & & & \\
\hline $92.3 \pm 0.8^{\mathrm{AB}}$ & $58.2 \pm 2.0^{\mathrm{BC}}$ & $90.3 \pm 0.8^{\mathrm{B}}$ & $86.6 \pm 1.4^{\mathrm{B}}$ & $98.1 \pm 0.1^{\mathrm{AB}}$ \\
$96.2 \pm 0.6^{\mathrm{A}}$ & $82.9 \pm 2.7^{\mathrm{A}}$ & $95.8 \pm 0.4^{\mathrm{A}}$ & $91.5 \pm 0.4^{\mathrm{A}}$ & $98.9 \pm 0.2^{\mathrm{A}}$
\end{tabular}

Chronic intake of sorbitol $(11+3 \mathrm{~d})$
$91.7 \pm 1.9^{\mathrm{Al3}}$
$52.2 \pm 1.7^{\circ}$
$85.3 \pm 1.5^{\mathrm{c}}$
$63.1 \pm 0.8^{13}$
$88.7 \pm 1.1^{\mathrm{n}}$
$87.6 \pm 1.0^{\mathrm{n}}$
$97.4 \pm 0.2^{\mathrm{BC}}$
$88.4 \pm 1.0^{\text {s }}$
$86.0 \pm 1.3^{\mathrm{B}}$
$98.0 \pm 0.3^{1 \mathrm{CC}}$
$90.4 \pm 1.8^{\mathrm{k}}$
$58.2 \pm 1.8^{\mathrm{loC}}$
$89.3 \pm 0.2^{13}$
$87.2 \pm 0.6^{\mathrm{B}}$
$97.7 \pm 0.1^{\mathrm{kC}}$

Acute intake of sorbitol ( 3 d)

$92.0 \pm 0.8^{\mathrm{AB}}$

$61.6 \pm 1.1^{\mathrm{B}}$

$90.7 \pm 0.6^{13}$

$89.2 \pm 0.6^{\mathrm{Als}}$

$98.2 \pm 0.1^{\mathrm{AB}}$

\section{Résumé}

Effet du sorbitol et des sels biliaires sur l'utilisation de l'aliment et la morphologie du foie, de la vésicule biliaire et des caeca chez le poulet en croissance

Des poulets mâles, d'une souche commerciale, âgés de 3 semaines sont utilisés pour étudier l'effet du sorbitol comparé à celui des sels biliaires sur les valeurs de l'énergie métabolisable apparente (EMA) et sur les coefficients d'utilisation digestive apparents des lipides (CUDL) d'un régime riche en lipides saturés (15 p. 100 de suif). Le régime est utilisé tel quel ou bien avec l'une des supplémentations suivantes : 0,$5 ; 1$ ou 2 p. 100 de sorbitol, ou 0,5 p. 100 de sels biliaires. Elles sont ajoutées au détriment du glucose. Deux périodes d'ingestion de sorbitol, courte et longue, sont comparées. De plus, l'efficacité alimentaire et les modifications morphologiques au niveau du foie, de la vésicule biliaire et des caeca sont également étudiées.

L'incorporation de sels biliaires dans le régime augmente significativement les valeurs d'EMA et de CUDL $(+4,6$ p. 100 et 16 p. 100 respectivement, $P<0,01)$. Par contre, le sorbitol ingéré pendant une période courte ou longue, et quelle que soit sa quantité dans le régime, n'affecte ni l'EMA, ni le CUDL.

Les poulets nourris avec le régime contenant des sels biliaires présentent des vésicules biliaires hypertrophiées. De plus, le poids de celles-ci, après lyophilisation, est significativement augmenté et plus que doublé $(\mathbf{P}<0,01)$. Enfin, quelle que soit la supplémentation, aucune modification au niveau du foie et des caeca n'est observée.

Mots clés : Sels biliaires, sorbitol, digestibilité des lipides, énergie métabolisable.

Received in August 1983.

Accepted in January 1984. 


\section{References}

Bauer K.D., Griminger P., 1980. Effect of dietary carbohydrates and biotin level on caecal size and biotin concentration of growing chickens. Poultry Sci., 59, 1493-1498.

Bezkorovainaya N.M., 1971. The effect of sorbitol on the biligenic function of the liver. Farmakol. Toksikol., 34 (5), 586-587.

Delpech P., Guezel M., Leclerce B., 1966. Méthode d'extraction des lipides en continu et à chaud par le mélange azéotrope : benzène-éthanol-eau. Rev. Fr. Corps Gras, 10, 615-620.

Dubich S.Ya., Kreknin A.F., 1969. The effect produced by sorbitol on biliation gastric duodenal and pancreatic juice secretion under normal conditions and in experimental pancreatitis. Farmakol. Toksikol., 32 (1), 75-78.

Eastwood M.A., 1973. Physiology of bile acids in the ileum and colon. Scot. Med. J., 18, $142-145$.

Folch J., Lees M., Slonne-Stanley G.H., 1957. A simple method for the isolation and purification of total lipids from animal tissue. J. Biol. Chem., 226, 497-509.

Gomez M.X., Polin D., 1974. Influence of cholic acid on the utilization of fats in the growing chicken. Poultry Sci., 53, 773-781.

Gomez M.X., Polin D., 1976. The use of bile salts to improve absorption of tallow in chicks, one to three weeks of age. Poultry Sci, 55, 2189-2195.

Grancharov V., 1973. Chologenic and choleretic action of sorbitol. Vopr. Pitaniya, 3 (2) : $50-54$.

Hakansson J., 1974. Factors affecting the digestibility of fats and fatty acid in chicks and hens. Swed. J. Agric. Res., 4, 33-47.

Hardison W.G.M., TomaszewSKi N., Grundy S.M., 1979. Effect of acute alterations in small bowel transit time upon the biliary excretion rate of bile acids. Gastroenterology, 76, $568-574$.

Katongole J.B.D., March B.E., 1980. Fat utilization in relation to intestinal fatty acid binding protein and bile salts in chicks of different ages and different genetic sources. Poultry Sci., 59, 819-827.

Kussaibati R., Guillaume J., Leclerce B., 1982 a. The effects of age, dietary fat and bile salts, and feeding rate on apparent and true metabolizable energy values in chickens. Br. Poult. Sci., 23, 393-403.

Kussaibati R., Guillaume J., Leclerce B., 1982 b. The effects of endogenous energy, type of diet and addition of bile salts on true metabolizable energy values in young chicks. Poultry Sci., 61, 2218-2223.

MaZANOWSKi A., MazANOwSKa A., 1965. A trial with adding sorbitol to concentrated mixtures for broilers. Drobiar Bull. Inf. (Poznan), 7 (3), 117-127.

Morgan T.B. and YudKIN J., 1962. The vitamin-sparing action of sorbitol, sugars and related substances. Vit. and Hormones, 20, 39-66.

Plessier J., 1960. Confrontation des actions cholécystokinétiques et cholérétiques de la cholécystokinine, du sorbitol, de l'huile d'olive et du sulfate de magnésie. Pathol. Biol. 8, 1201-1210.

Polin D., Hussein T.H., 1982. The effect of bile acid on lipid and nitrogen retention, carcass composition and dietary metabolizable energy. Poultry Sci., 61, 1697-1707.

RAWDON B.B., ANDREW A., 1981. An immunocytochemical survey of endocrine cells in the gastro-intestinal tract of chicks at hatching. Cell Tissue Res., 220, 279-292.

Small M., Dowling R.H., Redinges R.N., 1972. The enterohepatic circulation of bile salts. Arch. Int. Med., 130, 552-573.

Snedecor G.W., 1956. Statistical methods. The Iowa State College Press, AMES, Iowa.

Thivend P., Debarre Michèle, Lefaivre J., Toullec R., 1983. Etude de l'influe1.e du sorbitol sur la sécrétion biliaire chez le veau préruminant (in press). 